\title{
What is Obscenity? Morality and Modernity in 1920s China
}

\section{Yushu Geng}

\section{(2) OpenEdition}

\section{Journals}

Electronic version

URL: https://journals.openedition.org/chinaperspectives/10276

DOI: 10.4000/chinaperspectives. 10276

ISSN: 1996-4617

\section{Publisher}

Centre d'étude français sur la Chine contemporaine

Printed version

Date of publication: 1 September 2020

Number of pages: 9-17

ISSN: 2070-3449

\section{Electronic reference}

Yushu Geng, "What is Obscenity? Morality and Modernity in 1920s China", China Perspectives [Online], 2020-3 | 2020, Online since 01 September 2020, connection on 10 December 2021. URL: http:// journals.openedition.org/chinaperspectives/10276; DOI: https://doi.org/10.4000/chinaperspectives. 10276 


\title{
What is Obscenity? Morality and Modernity in 1920s China
}

\author{
YUSHU GENG
}

\begin{abstract}
This paper examines the debates over the meaning of obscene (yin 滛) in 1920s China. Although the censorial category yinshu (淫書 obscene books) long existed in imperial China, in the late 1910s and 1920s, commonly known as the May Fourth era, the meaning and content of this genre underwent intriguing changes following Chinese intellectuals' quest for enlightenment and modernity. As Kendrick Walter has insightfully remarked in his study of pornography in Western modern culture, "Pornography names an argument, not a thing" (1987: 31). The argument over the meaning of yin offers a unique perspective into the complicated relationship between science, morality, and modernity in Republican China.
\end{abstract}

KEYWORDS: Republican China, pornography, obscenity, modernity, morality, print culture, the cult of qing, Dream of the Red Chamber, Zhang Jingsheng.

\section{Introduction}

The discourse on 淫 (yin, obscene/licentious/lascivious/pornographic) in early twentieth century China has been gradually attracting scholarly attention in recent years. Within this body of pioneering works, Michel Hockx (2018) has explored the parameters of culturally acceptable representations of love and desire in 1910s China through his study of the banning of Eyebrow Talk (Meiyu 眉語), the first modern Chinese literary magazine to be banned as "obscene" by the Ministry of the Interior and the Ministry of Education in 1916, while Yvon Wang $(2014 ; 2019)$ has studied the police regulation of sexually titillating print materials in fin-de-siècle Beijing, arguing that new ideas of reproductive bodies and modern print technologies of mass reproduction were two crucial factors in negotiating the boundaries of legitimate sexual representations. Both have illuminated the enduring impact of late imperial pornographic representations in the early twentieth century, the constantly shifting line between "obscene" and "legitimate," and the much-neglected link between the arrival of modernity and the development of obscenity in Republican China. Building upon these observations and aiming to further enrich this history of obscenity, my own research focuses on the intellectual debates over the meaning of $y$ in in 1920s Chinese print culture. Through the study of attempts to negotiate the cultural parameters of yin, this paper aims to call attention to the oftenneglected tensions between morality and Western-derived, "scientistic" modernity in 1920 s China.

The history of pornography in Europe has been amply studied by scholars from different disciplines and continues to inform the study of Chinese-language sexually explicit materials (see for instance Walter 1987; Hunt 1993; Sigel 2005). However, Hunt's claim that "pornography as a legal and artistic category seems to be an especially Western idea with a specific chronology and geography" (1993: 10) has already proved problematic: scholars of late imperial Chinese literature have long noticed the presence of sexually explicit representations in late Ming and Qing (early seventeenth century to late nineteenth/early twentieth century) print culture as well as tenacious state efforts to regulate them (McMahon 1995; Vitiello 1996; Huang 2001; Wong 2007; Zamperini 2009). Within this ongoing reflection of Hunt's mistreatment of pornography as a distinctively modern European phenomenon, two important and interrelated issues linger: the problem of translating "pornography" into the Chinese context as a category of analysis, and the uneasy shadow cast by subtle Eurocentrism when assessing the link between "pornography" and "modernity."

The difficulty of translating "pornography" into Chinese is not merely a matter of linguistics, but is more a problem of the analytical usefulness of the category "pornography." Some scholars, such as Vitiello, have chosen to equate the late imperial censorial category 淫書 (yinshu, obscene books) with "the category of 'pornography' in Europe" (1996: 295). McMahon, having noted the commonalities between European and Chinese pornographic literature, similarly defended the viability of the word "pornography" in comparative studies (2018: 53-4). On the other hand, Zamperini has raised the problem that late imperial sexually explicit texts defied clear-cut genre definitions, and further questions the historical adequacy of the category of "pornography," a Western theoretical construct, in the analysis of late imperial Chinese printed matter (2009: 272-5). She insightfully suggests that late imperial sexually titillating texts should be seen and analysed as part of the yinshu canon, which, as an analytical category, could better uncover the arousing quality of the text among its readers and offer important answers to questions such as what exactly "pornography" is, and how it can engender sexual desire across time and culture (ibid: 296-7).

While Europe certainly does not own the word "pornography," and it is convenient to use it in the Chinese context from at least the Ming onwards, there are several reasons to prefer yinshu as an analytical category over "pornography" in this article: the unease about translating yinshu directly into "pornography" serves as a reminder that 
"pornography" has never been a given but must be understood within culturally, geographically, and temporally specific contexts. ${ }^{1}$ Yinshu continued to function as the censorial category in Republican China, and late imperial texts classified as yinshu in the Qing continued to be censored and banned by the Republican government. More importantly, the term yin became intricately linked with other keywords such as 性 (xing, sex/human nature) and 情 (qing, sentiment/passion/feeling), words that had long existed in imperial China but whose meanings underwent significant transfigurations during the early twentieth century as China became increasingly integrated into the global network of knowledge production and circulation. ${ }^{2}$ The analytical category of yinshu draws attention to attempts to differentiate between yin, xing, and qing in the 1920 s and the underlying cultural and intellectual currents supporting this negotiation of the boundaries of decency, an important facet of Chinese modernity that awaits further exploration.

Perhaps the most abiding legacy of Hunt's study of European pornography is her assertion of a direct link between modernity and pornography. For Hunt, early European pornography served political functions through its critiques of existing social and sexual order, and pornography as a regulatory category represented a response to the "perceived menace of the democratization of culture" (1993: 12-3; 40-5). For the Chinese context, Vitiello has stated that "the history of pornography in China parallels that of European pornography" (1996: 296), attributing the emergence of pornography in China to new philosophical attitudes towards desire and the material side of human nature in late Ming while reasserting Hunt's remark on the link between European pornography and Western modernity. The unresolved tension in Vitiello's argument is that, given his observation of parallels between the emergence of Chinese and European pornography in the seventeenth century, why should ideas generated from the Scientific Revolution, the Enlightenment, and the French Revolution become default signifiers of "modernity," whereas late Ming neo-Confucianism's refashioning of human nature and desire is denied the status of "modern"? While some scholars have attempted to trace the origin of Chinese modernity back to the seventeenth century or even earlier, the 1910s and 1920s, a time when Western ideas such as science and democracy became widely championed by contemporary Chinese intellectuals, continued to be hailed as ushering in the arrival of (Western) modernity in China (Zhang 2016: 483-4; Hockx 2018: 75). ${ }^{3}$ The problem here is, taking historically significant events in the Europe context as the benchmark of "modernity" inevitably renders May Fourth modernity a "belated modernity" that always attempted to but could never fully catch up with "the 'new' that is originated in and defined by the West" (Zhang 2016: 485).

To explore how the discourse of yin can help us understand the complexity of Chinese modernity in the 1920s without taking the West as the benchmark of modernity, I take an overall qualitative methodological approach in this paper and have conducted archival research on Chineselanguage newspapers and periodicals between the 1910s and 1930s. I have examined news and magazine articles that were related to the discussion of yin and yinshu, and analysed in detail the works of Zhang Jingsheng, whose self-claimed scientific sexological writings came to be regarded by both the Chinese state and the Chinese urban reading public as the most famous yinshu of the Republican era. This paper starts with a brief account of the legal ambiguities of yin in Republican press laws and then proceeds to discuss how the notions of qing and xing were employed to differentiate between yinshu and legitimate forms of publication.

\section{Legal ambiguities of yin in the Republican era}

This section focuses on the legal regulation of obscene books in the 1920s and 1930s. The new Chinese Republic under the Yuan Shikai government on 4 December 1914 issued its Press Laws, which contained articles prohibiting publications that would "harm social morals" (baihuai fengsuzhe 敗壞風俗者) (Song 2001: 546). They were later abolished in 1926 under increasing pressure from both the Chinese press and intellectuals, who regarded them as a repressive measure of the Yuan government against freedom of speech (Ting 1974: 12-4). After taking control over the majority of China in 1927, the Kuomintang (hereafter KMT) government issued new Press Laws in December 1930. They received minor revisions in 1935, which also prohibited publications that would "harm good social morals" (fanghai shanliang fengsuzhe 妨害善良風俗者) (Song 2001: 573). The exact meaning of "social morals," however, was never explained in these Press Laws. Moreover, the very word yin never appeared in any of these legal documents, even though almost all ordinances in the government gazettes (national or regional) used the censorial category yinshu when ordering inspections of the book market and the confiscation of said yinshu. In short, the terms yin and fengsu (風俗, social morals) seemed to be used as if their meanings were self-evident.

The legal ambiguities of fengsu and yin did not appear to be an acute problem for the police, who possessed the government-endorsed punitive power to fine and arrest anyone involved in the trade of yinshu. The police department of Shantou stated in 1924 that yin was indeed a vague term, but there was no need to differentiate yinshu and yinhua (渓畫, obscene pictures) from anatomy textbooks or artistic nudes, as "we policemen know our job well; as long as we take the right measures when dealing with obscene materials, there is no need to clarify to the public what counts as obscene and what does not." ${ }^{4}$ The implication was that a definition of yin was unnecessary and that law enforcement officers would know what was yin when they encountered it.

Given that ruling powers were highly fragmented during the Warlord era (1916-1928), and that the centralising and state-building efforts of the KMT regime in the 1930s and 1940s were fractured, the search for and punishment of those engaged in the trade of obscenity was largely carried out by parochial governing bodies, such as local police forces, or voluntary organisations that aimed to self-regulate the production of yinshu, such as the Shanghai's Book Association's Organisation of the Correction of the Mind (Shuye zhengxin tuan 書業正心團), which was formed in 1922 by leading Shanghai publishing houses. Individuals also wrote to the press,

1. I am aware that the category of yinshu does not adequately address visual sources that contained sexually explicit depictions, which were censored by the category of 渓畫 (yinhua, obscene pictures) in the Chinese context. The distinction made between yinshu and yinhua is another reason to question the analytical strength of the category "pornography" in the Chinese context: "pornography," being an umbrella term, often fails to address the nuanced difference and interplay between textuality and visuality. A more detailed discussion of this aspect is beyond the scope of this paper, but it is indeed a direction that awaits further elaboration.

2. For a history of the transformation of xing in modern China, see Rocha 2010b. The centrality of qing in Ming and Qing literature has been amply studied (Huang 1998; Huang 2001; Lee 2007). For a philosophical discussion of qing, see Middendorf 2008.

3. There are works exploring the connection between late imperial China and "the early modern," particularly the emergence of the cult of qing in late Ming and its connection to the formation of modern subjectivity (Lee 2007). But Lee also notes the difference between "the early modern" and Western-inspired May Fourth transformations of conceptions of subjectivity and identity, mostly that the late Ming cult of qing was still grounded in Confucian thinking and did not question the supremacy of ritual (2007: 36-8)

4. “公安局批示淫書畫查禁範圍文” (Gong'anju pishi yinshuhua chajin fanwei wen, Police Bureau's instruction on the scope of obscene books and pictures), Duobao 2, 1924 
denouncing the harmful impact of yinshu and supporting the ban on yinshu. ${ }^{5}$ Nonetheless, despite the lack of a cohesive state regulation of yinshu, the bourgeoning press networks of the Republican era helped to keep both institutions and individuals living in different regions informed about the ongoing nationwide effort to regulate obscenity. News of the formation of the Shuye zhengxin tuan quickly appeared in Beijing periodicals. ${ }^{6}$ Shanghai newspapers also reported on the hunt for yinshu and yinhua in Guangdong. ${ }^{7}$ While the policing of yinshu (and yinhua) were far from centrally organised and planned in the 1920s, it was clear that yin, manifested in the wide circulation of yinshu and yinhua, was regarded as a social concern that required regulation.

It is also worth pointing out that the regulatory category yinshu in the 1920s consisted of both late imperial sexually explicit texts and new texts that emerged in this period. The 1922 list of banned obscene books composed by the Chinese General Chamber of Commerce Shanghai was mainly made up of Ming and Qing fiction such as The Plum in the Golden Vase (linpingmei 金瓶梅), The Paradise of Apricot Blossoms (Xinghuatian 杏花天), A History of Debauchery (Langshi qiguan 浪史奇觀) and A Crazed Woman (Chipozi zhuan 痴婆子傳), although it did include a few books published in the late 1910s such as The Secret Diaries of A Female Student (Nüxuesheng mimi riji 女學生秘密日記). ${ }^{8}$ The 1930 banned obscene book list issued by the Shanghai Bureau of Social Affairs under the KMT government remained mostly identical to the 1922 list, other than the new addition of Zhang Jingsheng's Sex Histories (Xingshi 性史), which was published in $1926 .{ }^{9}$

The co-existence of the old and the new in the regulatory category of yinshu further complicated the relationship between pornography and modernity in the Chinese context. Scholars have previously argued that it was the subversive potential of pornography that made it crucial to the birth of new, modern culture (Hunt 1993; Zamperini 2009). In the case of the yinshu genre in the 1910s and 1920s, "the period par excellence when Western modernity made its way into China," such a link is difficult to maintain, as many texts labelled as yinshu were products of late imperial China and contained ideas - incest, orgies, and sodomy, for instance that would undoubtedly be harshly criticised by May Fourth iconoclasts (Hockx 2018: 75). While it is possible to assess whether a certain sexually explicit text has transgressive potential in a specific context, given the heterogeneous nature of the content of yinshu in the 1920s, it appears impossible to infer whether yinshu - the genre as a whole - was subversive or not.

For such reasons, I suggest that another productive way to rethink the link between yinshu and modernity is to ask how and why certain texts became classified as yinshu. The lack of a clear definition of yin and fengsu in official terms did open up space for contestation, at least discursively. ${ }^{10}$ The following sections will offer two case studies: the mixed reception of Dream of the Red Chamber (Hongloumeng 紅樓夢, hereafter referred to as Hongloumeng) in the 1920s, and the ways in which Zhang Jingsheng defended - albeit arguably unsuccessfully at that time - his Sex Histories from being labelled as yinshu.

\section{Yin and qing in the 1920s: The case of Hongloumeng}

Written in the mid-eighteenth century by Cao Xueqin, Hongloumeng is perhaps one of the most well-known and most publicly debated Chinese novels that straddles the obscene and the artistic. Although now widely celebrated as one of China's Four Great Classical Novels, it has been repeatedly banned since its birth on the grounds that its depictions of romance could incite obscenity (huiyin 誨淫).1" Liang Qichao, the influential late Qing reformer, spoke poorly of Hongloumeng in his "On Children's Education" (1896): he stated that Hongloumeng was popular among people due to its use of intelligible language rather than obscure classical Chinese and saw little value in it other than its ability to huiyin. Prominent intellectual figures of the May Fourth generation, including Lu Xun, Hu Shi, Chen Duxiu, and Zhou Zuoren, nevertheless valorised its literary merits and defended Hongloumeng against the accusation of yin. Lu Xun, for instance, in his A Brief History of Chinese Fiction claimed that the biggest achievement of Hongloumeng was that it not only broke all previous conventions of fiction writing, but also presented unprecedented new ideas. ${ }^{12}$ Lü Simian, the renowned Republican era historian, also argued that Hongloumeng was one of the most noble novels that depicted qing, and that it should not be confused with yinshu (cited from Zhang 1997). In short, Hongloumeng was fashioned as a milestone in the history of Chinese fiction and became one of the few late imperial texts that was incorporated into the literary canon by anti-Confucian, anti-tradition May Fourth iconoclasts.

The governmental ban on Hongloumeng lessened considerably from the late nineteenth century onward, particularly in comparison to the regulation of other sexually explicit late imperial novels such as Jinpingmei, which repeatedly appeared on the banned book lists well into the 1930s. However, despite (or precisely because of) the valorisation of its literary value in the May Fourth era, Hongloumeng continued to be cited in debates over the boundaries of yinshu. In this section I will first outline how contributors to New Culture (Xinwenhua 新文化), a journal edited and published by Zhang jingsheng in Shanghai in 1927, and Zhang Jingsheng himself differentiated Hongloumeng from yinshu by invoking the notion of qing. I then proceed to analyse how yin and qing were fundamentally gendered, and what this gendered nature tells us about Chinese modernity.

\section{Differentiating qing from yin}

The first issue of New Culture came out in 1927, a few months after the publication of Zhang Jingsheng's controversial book Sex Histories in 1926. Educated in France in the 1910s, Zhang returned to China in 1920 and taught Philosophy at Peking University in Beijing. ${ }^{13}$ In early 1926, he placed

5. Wuming 無明, “希望新聞界拒登淫書廣告” (Xiwang xinwenjie judeng yinshu guanggao, Hope the newspapers stop advertising for obscene books), Minguo ribao juewu 8(26), 1921; “濦書之害" (Yinshu zhi hai, The harms of obscene books), Shijie huabao 38, 1922.

6. “函商務印書館中華書局請勸告同業設立團體禁上印售淫書文” (Han shangwu yinshuguan zhonghua shuju qing quangao tongye sheli tuanti jinzhi yinshou yinshu wen, The Commercial Press and Chung Hwa Book Co. urged fellow trade associations to form organisations that prohibit the print of obscene books), Tongsu jiaoyu congkan 17, 1922.

7. Shouying 瘦影, "粵省淫書淫畫之末日” (Yuesheng yinshu yinhua zhi mori, The doom of obscene books and pictures in Guangdong), Shenbao, 2 March 1928.

8. Shanghai Municipal Archives (hereafter SMA): S-313-1-146.

9. SMA: S-313-1-148.

10. The concept of obscenity was of course challenged by forces both inside and outside political and intellectual institutions. Wang has discussed how the illiterate urban sellers of obscene materials in Beijing cited ignorance and destitution as reasons for engaging in the trade (2014), although it is unclear whether this line of argument had any impact on the literate urban reader-consumers of yinshu and yinhua.

11. For the banning of Hongloumeng in the Qing dynasty, see Zhao 2001; Zhang 2015. For a summary of the late imperial and early Republican debate over the literary merits of Hongloumeng, see Zhang 1997.

12. Lu Xun 魯迅, (1923-4; revised version published in 1930) 2006, 中國小説史略 (Zhongguo xiaoshuo shilüe, A Brief History of Chinese Fiction). Reprint, Beijing: Renmin wenxue chubanshe: 346. Citations refer to the Renmin chubanshe edition.

13. For more studies on the life and writings of Zhang, see Peng 2002; Rocha 2010a. 
advertisements in the literary supplement of Peking Gazettes (Jingbao fukan 京報副刊), encouraging readers to submit autobiographical accounts of their personal sexual experiences, and soon published a selection of these stories under the title Sex Histories. It was soon labelled a yinshu by the Ministry of Interior and banned across China. ${ }^{14}$ Zhang moved to Shanghai in 1926 amidst the chaos of the North Expedition as warlord Zhang Zuolin captured Beijing, and opened Aesthetics Bookstore (Meide shudian 美的書 店), under which he published the journal New Culture and a series of books with the goal of introducing Western sexology to China. The six issues of New Culture covered a wide range of topics related to gender and sexuality, ranging from sex education to women's inheritance rights. The journal became caught up in the debate over the meaning of yinshu, triggered by the controversy over Sex Histories. Hongloumeng was cited frequently in these discussions. Zhang published another book titled Sex Books and Obscene Books (Xingshu yu Yinshu 性書與渓書) in 1927, in which he also argued that Hongloumeng should be understood as qingshu 情書 (book of sentiment/love) rather than yinshu.

Zheng Binyu presented a brief etymology of the term yin in his article "On Obscene Books" in the second issue of New Culture. ${ }^{15}$ He argued eloquently that in classical Chinese yin had no connotations of sexual desire but referred to the lack of moderation and control. Yin should therefore be defined as excessive sex or promiscuity, rather than "all carnal desire between women and men." ${ }^{16}$ According to Zheng, Jinpingmei was yinshu, as it depicted characters who only thought about sexual intercourse, which was not the case in Hongloumeng. In a later issue, Chen Mengshao picked up on Zheng's comments on Hongloumeng, stating that both Hongloumeng and Water Margin (Shuihu zhuan 水滸傳) depicted "the true temperament of girl and boy heroes" (yingxiong ernü zhi zhen xingqing 英雄兒女之真性情) and had been wrongly labelled as yinshu. ${ }^{17}$ Chen claimed that the genre of the novel is about qing, and recognised that it could be dangerous for the reader to indulge too much in it. Nonetheless, it was the reader's overindulgence that should be blamed rather than novels depicting qing: Chen clearly expressed his disagreement with applying the label of yinshu to Hongloumeng. He was well aware of the popularity of Hongloumeng among prominent scholars of his time, citing Hu Shi's promotion of Hongloumeng to further validate its status as a non-obscene book. It is also worth noting that Chen adapted Hongloumeng into a play titled Lord of the Flowers (Jiangdong huazhu 絳洞花主) in 1927, for which Lu Xun wrote a preface.

Zhang Jingsheng further elaborated on the notion of Hongloumeng as qingshu in Sex Books and Obscene Books. Zhang argued that books that focused on the depiction of "love" (qing'ai 情愛) and occasionally involved descriptions of sexual activities should be classified as "sex books" (xingshu 性書) or qingshu, whereas books depicting sexual intercourse without love were yinshu (1927: 41). ${ }^{18}$ Zhang examined the sexual activities of Jia Baoyu (the male protagonist of Hongloumeng), who was deemed as "the most yin person in the world," stating that although jia Baoyu experienced sex at an unusually young age, we "considered that as human qing" (1927: 43-4). Zhang continued went on to say that, taking the great length of Hongloumeng and its central focus on the portrayal of human qing into consideration, even when Hongloumeng did occasionally touch on human sexual desire, it was always written in a very subtle way, and it was therefore unjust to simply render the whole book as yinshu (1927: 44-5). He then lamented that Chinese people only had sex for physical gratification rather than being motivated by qing when engaging in sexual intercourse, which, according to Zhang, was truly "the most yin persons in the world" (1927:
45). For such reasons, Zhang concluded that Chinese people needed books that depicted qing to save them (ibid.).

Haiyan Lee has illustrated compellingly that Hongloumeng's valorisation of qing signified an epistemic paradigm shift: it made qing the foundation of all relations and virtues, a radical departure from orthodox Confucian cosmic order, which centred around ritual principals and social ethics (2007: 45-50). She has further noted that Hongloumeng's celebration of qing became a forerunner for the May Fourth rebellion against repressive social order and its glorification of romantic love (Lee 2007:50). Although the exact meaning of qing was never explicitly explained in the texts from New Culture that this paper is analysing - it seems that Zhang's qing referred more specifically to romantic love/affection/feelings between women and men, while Chen's qing, as in "innate nature" (zhenxingqing 真 性情), referred to the notion of what is intrinsic in a person - well versed as they were in the contemporary celebration of the literary merits of Hongloumeng, Zhang, Chen, and Zheng did seem to pick up on the radical potential of the notion of qing in Hongloumeng. ${ }^{19}$ Either more narrowly defined as romantic love, or defined in a broader sense as referring to true temperament, qing was associated with authenticity and consequently was deemed noble.

On the other hand, despite the invocation of qing as a noble quality and the antithesis of yin in these texts, Zhang, Zheng, and Chen also took note of the vague line between qing and yin. The quantity of sexual intercourse was regarded as a crucial factor separating qing from yin. In his defence of Sex Histories, Zhang Jingsheng wrote in the first issue of New Culture: "I advocated having sex once a week, which could not be yin at all. Yin means excessive; asking adults to only have sex once a week of course was not yin, this was merely common sense."20 This notion was quoted by both Zheng and Chen as a key reason why Sex Histories and Hongloumeng were not yinshu, while both also warned the audience against the danger of overindulgence in qing, which could lead to yin. The solution for this elusive line between qing and yin, for the contributors to New Culture, lay in a scientific approach to sexual intercourse. I will turn to this aspect later in this paper. In the immediately following section I will focus on examining the mass public's attitude toward qing and yin.

\section{Gendered perceptions of qing and yin in the popular press}

It was not just highly-educated intellectuals who actively participated in the discussion concerning yin in the 1920s. The rapid development of the press in early twentieth-century China, particularly the growth of more commercial and entertainment-oriented newspapers and periodicals, offered a platform for the literate urban masses to voice their opinions.

14. Shen Ruilin 沈瑞麟, “內務部訓令第七十五號 ” (Neiwubu xunling diqishiwu hao, No.75 Order of the Ministry of Interior), Zhengfu gongbao 4071, 1927.

15. Zheng Binyu 鄭賓于 was the author of 中國文學流變史 (Zhongguo wenxue liubian shi, History of Chinese Literature), published in 1930. He studied at Peking University in the early 1920s and lectured at Fuzhou Xiehe University before going to work in Chengdu. This article was written when he was teaching in Fuzhou. For an account of available records of Zheng's life and work, see Xiong 2012.

16. Zheng Binyu 鄭賓于, “論淫書” (Lun yinshu, On obscene books), Xinwenhua 1(2), 1927.

17. Mengshao 夢韶, "新文化斷不是淫書” (Xinwenhua duan bushi yinshu, Xinwenhua is definitely not an obscene book), Xinwenhua 1(6), 1927. Mengshao is one of the pen names of Chen Mengshao.

18. See below for further elaboration on the notion of xingshu.

19. Zhang was involved in another debate in 1923 on the meaning of 愛 (ai, love). For a detailed analysis of this debate, see Lee 2007: 142-51.

20. Zhang Jingsheng, "新滔義與真科學" (Xin yinyi yu zhen kexue, New definition of obscenity and true science), Xinwenhua 1(1), 1926. 
Throughout the Republican era, less well-known and anonymous members of the urban reading public continued to submit pleas to newspapers and periodicals, condemning yinshu and calling for more thorough regulation of such texts. Hongloumeng continued to occupy a crucial place in the popular discourse of yin and qing, and these voices from the general population reveal an intriguing gendered dimension of the discourses of qing and yin.

In a 1922 article published in Shijie huabao that denounced the detrimental impact of yinshu, an anonymous writer wrote a sensational story about Lianyun, the only child of a wealthy family in Fengtian. Lianyun, a graduate of a girls' school, was an avid reader of romantic novels and was particularly fond of Hongloumeng. She was in her twenties and not yet married. For years, she often woke up from her dreams calling the name Bao gege (Brother Bao, the nickname for Jia Baoyu), and "qing led to sentimentality, sentimentality led to illness" (yinqing shengchou, yinchou zhibing 因情生愁, 因愁致病) as she grew weaker day by day. The author ended the story with a note that Lianyun was still thinking about Hongloumeng even on her deathbed, lamenting that "such was the harm of yinshu." 21

This 1922 fictional article might possibly be connected to a 1921 news report about a female fan of Hongloumeng who died because of her obsession with the book. Both Xinwenbao and Minguo ribao reported in October 1921 that a young woman from Beijing, Peng Huizhen, became obsessed with Hongloumeng and grew physically weaker each day. Her mother misinterpreted this as Peng's secret longing for marriage and tried to find a suitable match for her. But Peng refused to marry and revealed her desire for singlehood to her mother. Upon discovering that Peng was a devoted fan of Hongloumeng, her mother burned the book. Peng found out and cried, "You burned my Baoyu." Her health deteriorated rapidly and she died soon afterwards (cited in Zhang 2017: 333). Another similar but more elaborate story about the bad influence of Hongloumeng was published in 1926 in Sanri Huabao. Langu, living in Shanghai with her mother, fell in love and had sex with her cousin under the influence of Hongloumeng. She ended up pregnant, and her mother decided to approve their marriage after she discovered Langu's pregnancy. Unfortunately, Langu's father in Beijing, unaware of her romance with her cousin, send a letter telling Langu that he had arranged another match for her. Langu was so shocked after reading her father's letter that she fainted and died next day. At the end of the story, the author claimed that he reported this real event to warn those whom he considered to be "people full of or with an excess of qing" (duoging zhongzi 多情種子). ${ }^{22}$

Except for the 1922 piece, other articles did not explicitly label Hongloumeng as yinshu, nor was it clear whether such events really happened. It is nonetheless clear that there was concern over female obsession with Jia Baoyu, as well as a strong connection being made between Hongloumeng and sentimental, vulnerable young women who were easily trapped and endangered by qing in contemporary cultural imagination. While qing was widely used to differentiate Hongloumeng from yinshu throughout the 1910s to the 1930s, qing was also cited as the cause of women' doom and the reason why Hongloumeng was a harmful yinshu. The (mostly imagined) penalty for female readers of yinshu (or books that could arouse qing) appeared to be much more severe than that for male readers: in contemporary cautionary stories, women always became severely ill as they were consumed by qing and eventually faced death. In contrast, in articles advising men not to read yinshu, the rationale was always that yinshu would undermine their health, presumably because reading yinshu would lead to excessive masturbation, subsequently impairing their ability to serve the nation and society and to become a competent head of their household. One must ask: While many male intellectuals of the May Fourth era maintained that Hongloumeng was not yinshu (for men), to what extent was it considered a yinshu for women among the literate, urban reading public? Were qing and yin in fact seen as the same thing for women in the Republican era? In what ways were the female body and the male body treated differently in the discourse of obscenity?

The contemporary emphasis on the more detrimental impact of yinshu on women may be partially explained by the popularity of gender essentialism in the 1920s: notions such as women being naturally more gentle, emotional, fragile, and consequently more suitable for the domestic sphere were widely circulated in popular magazines such as Ladies' Journal (see Chiang 2004). The association of women's illness with qing also reflected the lasting influence of traditional Chinese medical discourse, which frequently used the notion of qing to explain and naturalise sexual differences between women and men. Zhang Jiebin, a late Ming physician, argued that women's illnesses were fundamentally the same as men's; it was only that women's qing were different from men's because their secluded lives resulted in many pent-up feelings. Zhang continued that women were consequently more prone to "affection, longing, love and hatred, envy and jealousy, and worry and rancour," and that qing made medical treatment of women more difficult than for men (cited from Wu 2010: 49).

In short, the notions of qing and yin were fundamentally gendered in the popular discourse of obscenity. The boundary between qing and yin seemed particularly fragile for women. It appeared much easier and more common for male intellectuals to argue that qing was not obscene but a noble quality, while in the popular press young women were usually depicted (by men) as victims of qing. If men were requested to beware of the harmful influence of yin, women were taught to be cautious of qing, which, for women, seemed to be a euphemism for yin.

\section{Morality and modernity}

The notion of qing has indeed been amply discussed among studies of Chinese modernity from an emotive perspective, but analysing it in tandem with the discourse of yin helps to uncover new tensions in Chinese modernity (Lean 2007; Lee 2007). Both Eugenia Lean and Lee have noted the significance of sentiment/emotion in the making of modernity and civic identity in early twentieth-century China. Lee has observed that May Fourth writers and thinkers, drawing from Western Enlightenment and Romanticist discourses, introduced "the enlightenment structure of feeling" in contrast to the previous "Confucian structure of feeling," and argued that this reconceptualization of identity and social order in emotive terms signified a fundamental transformation of modernity (2007: 15). Lean's study of Shi Jianqiao's assassination of warlord Sun Chuanfang and the subsequent media craze around this case in 1935 showed that female qing (which she translated into "sentiment") was an effective forum upon which debates about Chinese modernity took place. She has further noted that collective emotionalism embodied in the public empathy for Shi Jianqiao was seen by left-leaning writers in the 1930s as foolhardy, feminine, and a threat to their rational, "masculine" discourse of modernity (2007: 13, 77-106). The 1930s disdain of qing, Lean argued, was framed by the disillusion with May Fourth

21. “淫書之害” (Yinshu zhi hai, The harms of obscene books), Shijie huabao 38, 1922.

22. Hui Ying 惠英, “紅樓夢誤盡小兒女” (Hongloumeng wujin xiao ernü, Hongloumeng has harmed many young women and men), Sanri huabao 93, 1926 
celebration of romantic love as the way to create a modern social order, concerns with the rise of the irrational, unruly masses, and the valorisation of more "rational" discourses of modernity such as scientism and rule of law (2007: 84).

While Lee has rightly noted the power of the "enlightenment structure of feeling" in the May Fourth era, as with Lean's observation of the intellectuals' unease towards the opinions of the mass in the 1930s, we similarly detect a nuanced gap between the agenda of intellectuals and the general population's attitudes in the 1920s discourses of yin and qing. The concern over the impact of qing-yin on women testified not only to the enduring impact of traditional Chinese medical discourse but also the resilience of the Confucian way of social order that prioritised ritual over qing among the urban masses. The discourses of yin and qing in the 1920s also pointed to anxiety over the relationship between morality and modernity. For the intellectuals of the May Fourth generation, yin remained something objectionable and should not be confused with noble notions such as qing, which could contribute to national rejuvenation and modernisation. In other words, it seems that for both the May Fourth intellectuals and the urban masses, enlightenment and modernity had to be moral.

\section{Between xing, yin, and qing}

In this section, I examine another notion Zhang Jingsheng employed to differentiate the obscene from the non-obscene, namely, the notion of xing 性. The term xing, like the term qing, has existed since imperial times, but it became a new keyword that signified "sex" in early twentieth-century China (Rocha 2010). Whereas Zhang Jingsheng classified Hongloumeng as qingshu, he defined his Sexual Histories as a xingshu against the accusation of yinshu. What is of interest is that Zhang's notion of xingshu was not simply about science, but also involved a proliferation of qing. Through an examination of this xing-qing-yin discourse, I hope to further uncover the tension between morality and "scientistic" modernity.

Zhang Jingsheng presented four criteria that separated xingshu from yinshu in Sex Books and Obscene Books: firstly, depictions of sexual intercourse in xingshu should be "scientific." Zhang maintained that descriptions of sexual activities from physiological, psychological, pathological, and sociological perspectives were properly "scientific," while yinshu only focused on the portrayal of sexual intercourse per se without the provision of "knowledge" (xuewen 學問) (1927: 10-36). Secondly, xingshu emphasised the quality of sexual intercourse, while yinshu only stressed the quantity. Zhang used the example of Jinpingmei, claiming that it was yinshu because its protagonists were obsessed with sex and eventually died due to excessive amounts of sex. Here Zhang referred to his earlier argument in New Culture that his works were not yinshu, as they only advised people to have sexual intercourse once or twice per week (Zhang 1927: 37). The third criterion of xingshu was that xingshu depicted "appropriate (normal)" sexual intercourse (ibid.: 40). Zhang considered heterosexual intercourse as "appropriate/normal," stating that yinshu depicted the abnormal, such as same-sex intercourse and bestiality. Here Zhang noted the potential conflict between this principle and his first principle, clarifying that if homosexuality or fetishism was studied from a scientific perspective, it did not count as yinshu (ibid.: 41). His final criterion stated that books depicting qing'ai and containing occasional sexually explicit depictions were xingshu or qingshu, whereas books depicting sexual intercourse without qing'ai should be classified as yinshu. He summed up his key points on the distinctions between xingshu and yinshu in one sentence: "Books that adopt a scientific approach to depict appropriate, quality sexual intercourse that is motivated by love are xingshu. Conversely, books with no scientific foundation - that is, purely based on the author's nonsensical talk focused on the quantity of sex, abnormal kinds of sexual intercourse, and sex without love - are yinshu" (Zhang 1927: 45-6).

A major thread running through his argument was the notion that sex education was the most urgent task for contemporary Chinese; hence xingshu, which served important educational functions, should be celebrated rather than banned. Zhang contrasted Japan's successful Meiji Reform with China's failed reform attempts, citing the poor quality of the Chinese race as the major reason for China's decline. ${ }^{23}$ He claimed that "sexology" (xingxue 性學) was of paramount importance for "saving the nation and saving the race" (jiuguo jiuzhong 救國救種), more important than any other kind of science (1927: 12). Zhang invoked eugenics to argue that xingxue were concerned with human reproduction and were therefore crucial to the improvement of the Chinese race: "If we do not discuss xingxue, the entire race will be of bad quality; there will be no way to study any kind of knowledge at all" (ibid.). Zhang was aware of the potential arousing effect of Sex Histories on its readers, but he insisted that such sexual urges were normal reactions that should not be repressed but properly guided. He stated, "We are not concerned about young people's sexual urges; we only worry that they may act recklessly on such sexual urges or overindulge in such urges" (1927: 14-5). Sex Histories, according to Zhang, in fact educated young people, who previously had no proper knowledge of how to handle their sexual urges and consequently ended up masturbating or having sexual intercourse in other wrong ways (1927: 15). ${ }^{24}$

It is interesting that educational materials concerning sex increased steadily at the same time as Zhang Jingsheng acquired the nickname Dr. Sex (Xing boshi 性博士) and a scandalous reputation for writing yinshu. In the 1920s, both educational and medical journals published special issues on sex education, and women's magazines such as Ladies' Journal and Linglong also discussed issues ranging from children's sex education to the anatomy of women, contraception methods, and sexual morality. Such public discussions, however, never triggered the same scale of controversy as Zhang's Sex Histories and later theories of "the third fluid of women." Perhaps one explanation for Sex Histories' infamous reputation as yinshu, as well as the biggest difficulty for Sex Histories to hold onto its claim as a scientific study, was its rather literary style of story-telling. Both proand anti-Sex Histories readers regarded its resemblance to the novel genre as highly problematic: one contemporary commentator insisted that Sex Histories adopted a literary rather than scientific way of depicting sexual desire, "which was just like previous yinshu such as Chipozi zhuan." 25 Zhou Zuoren, while initially opposed the governmental ban of Sex Histories in 1926, nonetheless maintained that its "fictional writing style" was its biggest shortcoming (1927, cited in Zhong 1998: 177). Even Zhang himself, in his memoirs published in the 1950s, recalled that Sex Histories

23. Interestingly, Zhang did not blame the inferior quality of the Chinese race on the inferiority of Chinese women, which was a common trope since the late Qing. Zhang claimed that Sex Histories championed women's rights and aimed to stand up for women, who experienced much injustice. He also argued that proper sex education would help women enjoy sex, which would not only benefit women themselves, but also produce stronger infants. The role of Zhang jingsheng in women's liberation awaits further elaboration.

24. Zhang also used the readers' correspondence column in New Culture to disseminate knowledge of sexual activities and assumed a mentor role for the young, literate urban youth confused by sex. For more discussion of this aspect, see Rocha 2010a.

25. Baitou 白頭, "性史與滛書” (Xingshi yu yinshu, Sex Histories and obscene books), Beiyang Huabao 54, 1927 
had the problem of being too literary and should have been written in a "non-fictional style" (1998: 108). Moreover, contemporary scholars interested in sexology did not always recognise Zhang's sex-related works as xingshu, nor did they see such works as proper sex education materials. Zhou Zuoren and Pan Guangdan, both well informed on Western sexology, harshly criticised the lack of scientific foundation in Zhang's theories. Zhou, although stating that he did not think there was "anything morally wrong" about Sex Histories and that it was "worth reading," condemned Zhang's promotion of the douche for birth-control (1924, cited from Zhong 1998: 174-5).

I want to suggest, however, that the narrative style of Sex Histories was only one of the reasons why it was disqualified as an educational piece, and that there was a deeper argument beneath the contemporary critique of Zhang's lack of scientific knowledge among other May Fourth intellectuals. Peng Hsiao-yen has recently studied the counter-Enlightenment strand of ideas during the May Fourth era and traced how intellectuals such as Cai Yuanpei used the notion of qing (she translates it as "affect") to criticize scientism, which she considers a challenge of "Enlightenment sentimentality" to "Enlightenment rationality and scientism" (2019). Peng considers Zhang Jingsheng's popularisation of aesthetics, as reflected in his 1925 work The Philosophy of a Beautiful Life (Mei de renshenguan 美的人 生觀), a branch of this "Enlightenment sentimentality." I agree with Peng that Zhang's works display a highly ambivalent attitude toward scientism. Both The Philosophy of a Beautiful Life and How to Organize a Beautiful Society (Mei de shehui zuzhifa 美的社會組織法, 1925) emphasised the importance of sex education in organising a harmonious modern society, and this notion was further developed in Sex Books and Obscene Books. Zhang wrote:

From now on the most important thing for education in China is that it should take qing'ai as its foundation, for Chinese people are severely lacking in qing'ai. (...) why do Chinese people lack sympathy? Why do Chinese people have no patriotic values? Why do they not study hard? Why do they quarrel so much in their households? Why is there no affection between husbands and wives? Why is it that all we see are people without qing, as well as fake, sneaky, and deceitful people? It is all because of the lack of qing'ai. But why is there a lack of qing'ai? It is because there is no foundation of sexual desire. In a nutshell, qing'ai is the higher version of sexual desire, and sexual desire is the basic element of qing'ai. Hence, in order to save this qing'ai deficient country, the most fundamental problem is that of sex education. (1927: 80)

What is of interest here is the tangled relationship between qing and science. Sex education was the most important issue for China, as it could help the Chinese people develop qing, which Zhang believed would solve all problems ranging from domestic quarrels to national rejuvenation. Qing was therefore of paramount importance, whereas sex education was the means through which qing could be perfected. Xingshu and xingxue, in other words, were at the service of qing. Zhang stated clearly that xingshu needed to adopt a scientific approach, but at the same time, it was qing rather than scientism that emerged as the organising principle of the kind of ideal modern society he envisioned. Zhang's sexological works could be located within the counter-enlightenment trends in the May Fourth era, in the sense that they were not anti-enlightenment but rather stressed the role of qing (affect) alongside rationality in enlightenment and progression.

On the other hand, for Zhang, a scientific understanding of sexual intercourse was also what prevented qing from slipping into the dangerous, undesirable arena of yin. Only a scientific understanding of sex could prevent overindulgence, masturbation, homosexuality, and other sexual activities he deemed to be abnormal. In Zhang's case, it was the combination of qing and science (qing as the organising, foundational principle and science as the means to develop qing) that could bring the modern. And the notion that enlightenment and modernity had to be moral persisted; yin could never be modern, and Zhang explicitly stated that he wished the government would ban yinshu and promote xingshu (1927: 25).

\section{Conclusion}

The notion of yin in 1920s China was shaped by a multitude of ideas: May Fourth transfiguration of the late imperial cult of qing, the celebration of science, and the enduring impact of Confucian cosmological order. Such temporal complexities within the discourse of yin defy a clear linear narrative of the relationship between modernity and "pornography." Likewise, the gap between the perceptions of intellectuals and those of the emerging literate urban masses, as well as the heterogeneous nature of yinshu, made it difficult to speak of the transgressive nature of the genre of yinshu as a whole.

Nonetheless, through an examination of attempts to negotiate the boundaries of yinshu, we see that qing was indeed crucial to the making of modernity in the May Fourth era. Discourses on yin and qing were framed differently depending on whether the target audience was men or women. The fragile line between qing and yin also pointed to many tensions within modern culture, such as the relationship between morality and modernity, the entangled rather than antagonistic relationship between reason and affect, and the gender differentiation developing within the culture of modernity.

\section{Acknowledgements}

I thank all the participants in the 2019 CHANGE conference "Reenvisioning Gender in China" for their comments on an earlier draft of this paper. Especially useful were the suggestions made by Jennifer Altehenger, Françoise Lauwaert, and Doris Sung. I am also grateful for the constructive remarks of Coraline Jortay, Jennifer Bond, my supervisor Rachel Leow, and the two anonymous reviewers, as well as for the help of Liu Chang in the publication process.

\section{Yushu Geng is a PhD candidate in History at the University of Cambridge, West Road, Cambridge CB3 9EF, UK. Her research focuses on gender and women in late nineteenth and early twentieth-century China (yg317@cam.ac.uk).}

\section{Manuscript received on 23 August 2019. Accepted on 24 April 2020.}




\section{Primary Sources}

1921. “淫書之害” (Yinshu zhi hai, The harms of obscene books). Shijie huabao 38.

1922. “函商務印書館中華書局請勸告同業設立團體禁止印售 淫書文" (Han shangwu yinshuguan zhonghua shuju qing quangao tongye sheli tuanti jinzhi yinshou yinshu wen, The Commercial Press and Chung Hwa Book Co. urged fellow trade associations to form organizations that prohibit the print of obscene books). Tongsu jiaoyu congkan 17.

1924. “公安局批示淫書畫查禁範圍文” (Gong'anju pishi yinshuhua chajin fanwei wen, Police Bureau's instruction on the scope of obscene books and pictures). Duobao 2.

Baitou 白頭. 1927. "性史與淫書" (Xingshi yu yinshu, Sex Histories and obscene books). Beiyang Huabao 54.

Huiying 惠英. 1926. “紅樓夢誤盡小兒女” (Hongloumeng wujin xiao ernü, Hongloumeng had harmed many young women and men). Sanri huabao 93.

LU, Xun 魯迅. [1923-4; revised version published in 1930] 2006. 中 國小説史略 (Zhongguo xiaoshuo shilüe, A Brief History of Chinese Fiction). Reprint, Beijing: Renmin wenxue chubanshe.

Mengshao 夢韶. 1927. "新文化斷不是淫書" (Xinwenhua duan bushi yinshu, Xinwenhua is definitely not an obscene book).Xinwenhua 1(6).

Shanghai municipal archives: S-313-1-146; S-313-1-148.
SHEN, Ruilin 沈瑞麟. 1927. “內務部訓令第七十五號” (Neiwubu xunling diqishiwu hao, No.75 Order of the Ministry of Interior). Zhengfu gongbao 4071.

Shouying 瘦影. 1928. “粵省淫書淫畫之末日” (Yuesheng yinshu yinhua zhi mori, The doom of obscene books and pictures in Guangdong). Shenbao, 2 March 1928.

Wuming 無明. 1922. “希望新聞界拒登淫書廣告” (Xiwang xinwenjie judeng yinshu guanggao, Hope the newspapers stop advertising for obscene books). Minguo ribao juewu 8.

ZHANG, Jingsheng 張競生. [1950s] 1998. 十年情場 (Shinian qingchang, Ten years of my love adventures). Singapore: Yedeng baoshe. Reprinted in 張競生文集下卷 (Zhang Jingsheng wenji xiajuan, Collected Works of Zhang Jingsheng Vol. 2). Edited by Jiang Zhongxiao 江中孝. Guangzhou: Guangzhou chubanshe.

ZHANG, Jingsheng 張競生. [1926] 2014. 性史 (Xingshi, Sex Histories). Reprint, Beijing: Shijie tushu chuban gongsi.

ZHANG, Jingsheng 張競生. 1927. 性書與淫書 (Xingshu yu yinshu, Sex books and obscene books). Shanghai: Meide shudian.

ZHANG, Jingsheng 張競生. 1926. “新淫義與真科學” (Xin yinyi yu zhen kexue, New definition of obscenity and true science). Xinwenhua 1(1).

ZHENG, Binyu 鄭賓于. 1927. “論淫書” (Lun yinshu, On obscene books). Xinwenhua 1(2).

\section{References}

CHIANG, Yung-chen 江勇振. 2004. “男人是人，女人只是他者: '婦 女雜志'的性別論述” (Nanren shi ren, nüren zhishi tazhe: Funü Zazhi de xingbie lunshu, The masculine universal and the feminine other: gender discourse in the Ladies' Journal). Jindai Zhongguo funüshi yanjiu 12: 3967.

HOCKX, Michel. 2018. "Raising Eyebrows: The Journal Eyebrow Talk and the Regulation of 'Harmful Fiction' in Modern China." In Michel Hockx, Joan Judge, and Barbara Mittler (eds.), Women and the Periodical Press in China's Long Twentieth Century: A Space of Their Own?. Cambridge: Cambridge University Press. 74-92.

HUANG, Martin W. 2001. Desire and Fictional Narrative in Late Imperial China. Cambridge, MA: Harvard University Press.

HUANG, Martin W. 1998. "Sentiments of Desire: Thoughts on the Cult of Qing in Ming-Qing Literature." Chinese Literature: Essays, Articles, Reviews (CLEAR) 20: 153-84.

HUNT, Lynn. 1993. "Introduction." In Lynn Hunt (ed.), The Invention of Pornography: Obscenity and the Origins of Modernity, 1500-1800. New York: Zone. 9-45.
LEAN, Eugenia. 2007. Public Passions: The Trial of Shi Jianqiao and the Rise of Popular Sympathy in Republican China. Berkeley and Los Angeles: University of California Press.

LEE, Haiyan. 2007. Revolution of the Heart: A Genealogy of Love in China, 1900-1950. Stanford, CA: Stanford University Press.

MCMAHON, Keith. 1995. Misers, Shrews, and Polygamists: Sexuality and Male-Female Relations in Eighteenth-Century Chinese Fiction. Durham, NC: Duke University Press.

MCMAHON, Keith. 2018. "The Pornographic Doctrine of a Loyalist Ming Novel: Social Decline and Sexual Disorder in Preposterous Words (Guwangyan)." In Howard Chiang (ed.), Sexuality in China: Histories of Power and Pleasure. Seattle: University of Washington Press. 50-75.

MIDDENDORF, Ulrike. 2008. "Again on 'Qing'. With a Translation of the Guodian 'Xing Zi Ming Chu'." Oriens Extremus 47: 97-159.

PENG, Hsiao-yen. 2002. "Sex histories: Zhang Jingsheng's sexual revolution." In Peng-hsiang Chen and Whitney Crothers Dilley (eds.), Feminism/Femininity in Chinese Literature. New York: Editions Rodopi B.V. 159-78. 
PENG, Hsiao-yen 彭曉奸. 2019. 唯情與理性的辯證: 五四的反啓蒙 (Weiqing yu lixing de bianzheng: wusi de fanqimeng, Dialectics between affect and reason: the May Fourth counter-enlightenment). Xinbei: Liaojing chuban.

ROCHA, Leon. 2010a. "Sex, Eugenics, Aesthetics, Utopia in the Life and Work of Zhang Jingsheng (1888-1970)." PhD thesis, Cambridge University.

ROCHA, Leon. 2010b. "Xing: The Discourse of Sex and Human Nature in Modern China." Gender and History 22(3): 603-28.

SIGEL, Lisa Z. (ed.). 2005. International Exposure: Perspectives on Modern European Pornography, 1800-2000. New Brunswick: Rutgers University Press.

SONG, Yuanfang 宋原放 (ed.). 2001. 中國出版史料: 現代部分第一 卷 (Zhongguo Chuban Shiliao: Xiandai bufen diyi juan, Historical sources of Chinese publishing: modern part vol.1). Ji'nan: Shandong jiaoyu chubanshe.

TING, Lee-hsia Hsu. 1974. Government Control of the Press in Modern China, 1900-1949. Cambridge, Mass.: East Asian Research Center, Harvard University.

VITIELLO, Giovanni. 1996. "The Fantastic Journey of an Ugly Boy: Homosexuality and Salvation in Late Ming Pornography." Positions 4(2): 291-320.

WALTER, Kendrick. 1987. The Secret Museum: Pornography in Modern Culture. New York: Penguin.

WANG, Y. Yvon. 2014. "Whorish Representation: Pornography, Media, and Modernity in fin-de-siècle Beijing." Modern China 40(4): 351-92.

WANG, Y. Yvon. 2019. "Yellow Books in Red China: A Preliminary Examination of Sex in Print in the Early People's Republic." TwentiethCentury China 44(1): 75-97.

WONG, Ka. 2007. "The Anatomy of Eroticism: Reimagining Sex and Sexuality in the Late Ming Novel Xiuta Yeshi." Nan Nü 9(2): 284-329.

WU, Yi-Li. 2010. Reproducing Women: Medicine, Metaphor and Childbirth in Late Imperial China. Berkeley and Los Angeles: University of California Press.
XIONG, Feiyu 熊飛宇. 2012. “'中國文學流變史' 作者鄭賓于生平 考略" ("Zhongguo wenxue liubianshi" zuozhe Zheng Binyu shengping kaolue, A study of Zheng Binyu, the author of History of Chinese Literature). Chongqing wenli xueyuan xuebao (shehui kexue ban) 31(3): 49-52.

ZAMPERINI, Paola. 2009. "Canonizing Pornography. Norm and Transgression in Chipozi zhuan." In Jianyu Zhou 周建渝, Hongnian Zhang 張洪年, and Shuangqing Zhang 張雙慶 (eds.), 重讀經典: 中國傳統 小説與戲曲的多重透視 (Chongdu jingdian: Zhongguo chuantong xiaoshuo yu xiqu de duochong toushi, Re-thinking the Canon in Traditional Chinese Fiction and Drama). Hong Kong: Oxford University Press. 270-98.

ZHANG, Tianxing 張天星. 2017. “民國新聞報”所載“紅樓夢'稀見史 料論札" (Minguo "Xinwenbao" suozai "Hongloumeng" xijian shiliao lunzha, Rare historical records of Hongloumeng on Xinwenbao during the Republican era). Hongloumeng xuekan 3: 320-39.

ZHANG, Tianxing 張天星. 2015. “晚清報載禁毀'紅樓夢'史料輯 釋" (Wanqingbao zai jinhui "Hongloumeng" shiliao jishi, Edition of the historical sources of banned Hongloumeng in the Wanqingbao). Hongloumeng xuekan 6: 320-39.

ZHANG, Yingjin. 2016. "Toward a Typology of Literary Modernity in China: A Survey of English Scholarship on Modern Chinese Literature." In Yingjin Zhang (ed.), A Companion to Modern Chinese Literature. London: WileyBlackwell. 483-500.

ZHANG, Zongwei 張宗偉. 1997. “世紀之交的回顧 - 析紅樓夢誨淫非 滛之爭" (Shiji zhijiao de huigu - Xi Hongloumeng huiyin feiyin zhizheng, Reflections on the turn of the century - analysing the debate over whether Hongloumeng was obscene). Hongloumeng xuekan 3: 324-37.

ZHAO, Weiguo 趙維國. 2001. “紅樓夢禁毀始末考述” (Hongloumeng jinhui shimo kaoshu, A complete account of the banning of Hongloumeng). Hongloumeng xuekan 3: 205-21.

ZHONG, Shuhe 鐘叔河 (ed.). 1998. 周作人文類編 卷五 (Zhou Zuoren wenlei bian juanwu, Collective works of Zhou Zuoren Vol. 5). Changsha: Hunan wenyi chubanshe. 